\title{
Influence of pin geometry on mechanical and structural properties of butt friction stir welded 2024-T351 aluminum alloy
}

\author{
Igor Z. Radisavljevic ${ }^{1}$, Aleksandar B. Zivkovic ${ }^{2}$, Vencislav K. Grabulov ${ }^{3}$, Nenad A. Radovic ${ }^{4}$ \\ ${ }^{1}$ Military Technical Institute, Belgrade, Serbia \\ ${ }^{2}$ GOSA FOM, Smederevska Palanka, Serbia \\ ${ }^{3}$ Institute for Materials Testing, Belgrade, Serbia \\ ${ }^{4}$ Faculty of Technology and Metallurgy, Belgrade, Serbia
}

\begin{abstract}
The aim of this work was to investigate the combined effect of small difference in pin geometry, together with rotation and welding speed on the weldability, mechanical and structural properties of FSW 2024-T351 Al plates. The only difference in tool pin design was the shape of thread: regular and rounded. Specimens were welded using rotation rate of $750 \mathrm{rev} / \mathrm{min}$ and welding speeds of 73 and $93 \mathrm{~mm} / \mathrm{min}$. Specimens were defect free, with good or acceptable weld surface, in all four cases. Modification in pin design showed strong influence on macro structure and hardness distribution. Weak places are identified as low hardness zone, close to the nugget zone and are in good agreement with fracture location in tensile testing. Weld efficiency, as a measure of weld quality, is better in case of 310 tool, while UTS values can differ up to $13 \%$ for the equal welding parameters. Therefore, it can be assumed that small modification in tool design, particularly in pin geometry, can have great influence on weld formation and mechanical properties.
\end{abstract}

Keywords: friction stir welding, pin geometry, weld quality, Al alloy 2024, heat input.

SCIENTIFIC PAPER

UDC 621.791.1:669.715

Hem. Ind. 69 (3) 323-330 (2015)

doi: 10.2298/HEMIND131206020R

Available online at the Journal website: http://www.ache.org.rs/HI/

Friction stir welding (FSW), a solid-state joining technique invented by TWI in 1991 is new welding technique that offers several advantages over conventional fusion welding process due to its low heat input and absence of melting and solidification [1-3]. FSW run in the solid phase below the melting point of joining materials, approximately at 0.8 of $\mathrm{Tm}$ [4]. Therefore, due to absence of melting, weld metal is not pre- sent, while new region are introduced: nugget zone (NZ) and thermo-mechanically affected zone (TMAZ), Figure 1a. The most important benefit of FSW is its ability to weld materials that are extremely difficult to weld by conventional fusion welding processes, such as 2xxx and 7xxx series aluminum alloys. The benefits therefore include low distortion and residual stresses, no loss of alloying elements, no arc, no fume and no

a)

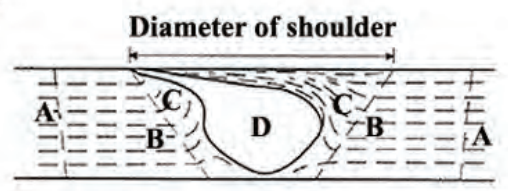

b)

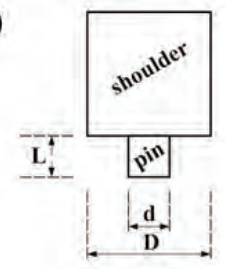

c)

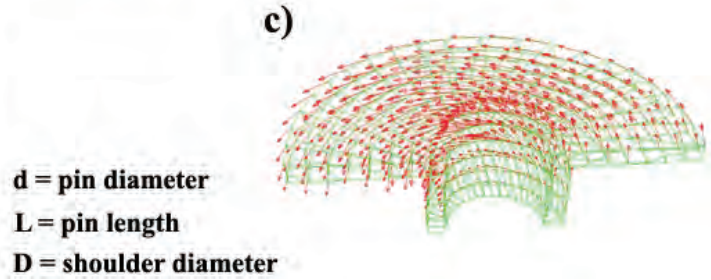

Figure 1. Schematic illustration a) regions of FSW joint: A-base metal (BM), B-Heat Affected Zone (HAZ), C-Thermo-Mechanically Affected Zone (TMAZ), D-Nugget zone (NZ); b) FSW tool; c) material flow during FSW process [5].

Correspondence: I.Z. Radisavljevic, Military Technical Institute, Ratka Resanovica 1, 11030 Belgrade, Serbia.

E-mail: igor.radisavljevic@vti.vs.rs

Paper received:

Paper accepted: filler wire. Moreover, due to low heat input and the absence of a melting and solidification, high quality welds with minimal microstructural changes and better mechanical properties than conventional welding, with- 
out presence of porosity and hot cracking can be created [4,6-8]. Thus, FSW is a very suitable, and increasingly used, for joining high strength aluminum alloys (2xxx, 6xxx, 7xxx and 8xxx series), currently applied to the aerospace, automotive, marine and military industries.

Friction stir welding tool, Figure $1 \mathrm{~b}$, is the key art of FSW process [2-4,9-14]. Typical flow of material during FSW is illustrated on Figure 1c. Significant research is done in order to obtain sound welds (in terms of UTS, elongation, weld microstructure, hardness, fatigue resistance etc.) and to establish the influence of welding parameters (rotation and welding speed), tool geometry and position of the pin axes [15-20]. On the other hand, heat generation and material flow (together with final structure and weld mechanical properties) are directly related to the tool shoulder and pin geometry.

Shoulder is the main source of heat generated during the process, the primary constraint to material expulsion and the primary driver for material flow around the tool, the pin is the primary source for material deformation and the secondary source for heat generation in the nugget. Nugget integrity is therefore primarily dependent on a well-designed pin. Furthermore, pin geometry also can affect the weld shape. Consequently, the geometry of both the shoulder and pin are important to the FSW process, since they determine the heat generation and material flow $[4,5,9,21-$ $-25]$.

Main aim of this work is to establish the effect of pin thread geometry on the weldability, mechanical and structural properties of friction stir welded 2024T351 Al plates for constant set of welding parameters (rotation speed and welding speed).

\section{EXPERIMENTAL}

Commercial $8.0 \mathrm{~mm}$ thick Alclad 2024-T351 aluminum alloy rolled plates were used in this work as the base metal. Plates were machined on both sides to remove the Alclads. Chemical compositions and mechanical properties of the machined plate are given in Table 1. Single welded plates were dimension of 260 $\mathrm{mm} \times 65 \mathrm{~mm} \times 6 \mathrm{~mm}$. Sides of plates were machined and had stiff contact with supporting plate, and buttwelded along the rolling direction using adopted conventional milling machine. Welding length was approx. $210 \mathrm{~mm}$ on each pair of plates. Two different friction stir tools were designed; the only difference was pin design, i.e., use of regular (tool 310) or rounded (tool 310-0) threads, Figure 2. Used tools are made of tool steel, with spiral thread on the $5.5 \mathrm{~mm}$ length conical pin and concave profiled head on the $25 \mathrm{~mm}$ diameter cylindrical shoulder. Taper screw thread pins are designed, with thread slope of 5 degrees and diameter on root and head of 10 and $4 \mathrm{~mm}$, respectively. Pins have angle of 20 degrees. Pitch of thread is $1.5 \mathrm{~mm}$. The tools are heat treated to 51 HRC. Tool tilt angle was $1^{\circ}$ and was kept constant. An equal axial (welding) force is obtained by controlling the plunge depth of welding tool, since all the specimens have the same thickness. Plunge depth of tool shoulder was $0.2 \mathrm{~mm}$. All welded joints are in "hot" condition; according to $R / V$ ratio criterion suggested by $\mathrm{P}$. Vilaça et al. $[2,26]$. $R$ represents tool rotation speed per minute (rpm) and $V$ is welding speed in $\mathrm{mm} / \mathrm{min}$. Welding parameters used in this study are summarized in Table 2, where ratio $R^{2} / V$ represents pseudo heat index suggested by Arbegast and Hartley [27].

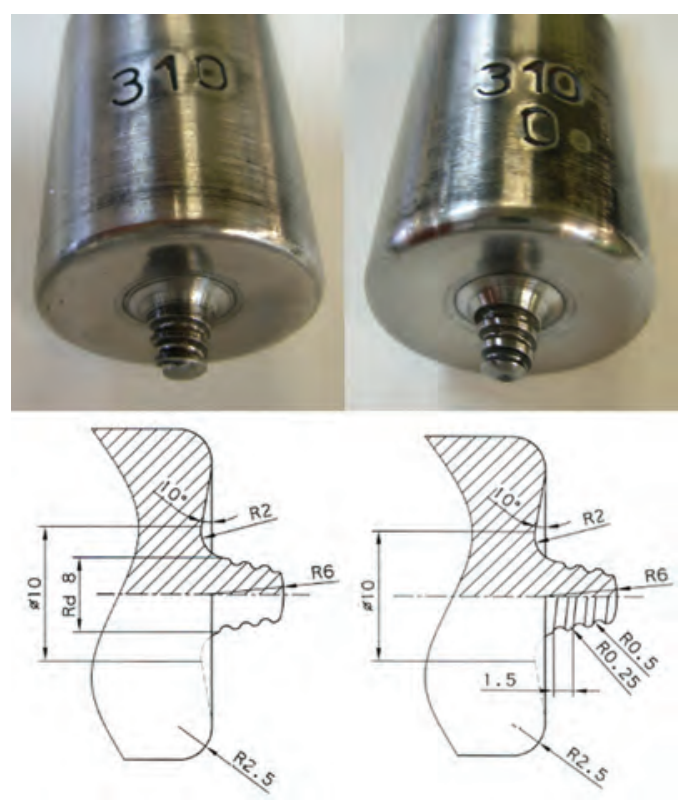

Figure 2. Fabricated FSW tools.

Complete testing methodology is given in Table 3. In order to reveal presence of surface and/or volume defects, welded joints were subjected to visual, penetrants, X-ray and ultrasonic examination. These steps are eliminating, i.e., if the joint does not fulfill requirements, it was eliminated from further examination. All welded samples were naturally aged at room temperature for more than 20 days and specimens were cross-

Table 1. Chemical composition and mechanical properties of Al 2024-T351 plate; BA - banding angle

\begin{tabular}{|c|c|c|c|c|c|c|c|c|c|c|c|c|c|c|}
\hline \multicolumn{10}{|c|}{ Chemical composition, wt.\% } & \multicolumn{5}{|c|}{ Mechanical properties } \\
\hline $\mathrm{Cu}$ & $\mathrm{Mg}$ & $\mathrm{Mn}$ & $\mathrm{Fe}$ & $\mathrm{Zn}$ & $\mathrm{Si}$ & $\mathrm{Ti}$ & $\mathrm{Zr}$ & $\mathrm{Ni}$ & $\mathrm{Cr}$ & $Y S / \mathrm{MPa}$ & UTS / MPa & $A_{5} / \%$ & $H V$ & $B A$ \\
\hline 4.70 & 1.56 & 0.65 & 0.17 & 0.11 & 0.046 & 0.032 & 0.011 & 0.006 & 0.004 & 370 & 481 & 18 & 145 & 180 \\
\hline
\end{tabular}


Table 2. Welding parameters

\begin{tabular}{lcccccc}
\hline Sample & Tool designation & $\begin{array}{c}\text { Rotation rate }(R) \\
\mathrm{rpm}\end{array}$ & $\begin{array}{c}\text { Welding speed }(V) \\
\mathrm{mm} / \mathrm{min}\end{array}$ & $\begin{array}{c}\text { Ratio } R / V \\
\text { rev/mm }\end{array}$ & Ratio $R^{2} / V$ & $\begin{array}{c}\text { Ratio } V / R \\
\mathrm{~mm} / \mathrm{rev}\end{array}$ \\
\hline $\mathrm{A}$ & 310 & 750 & 73 & 10.27 & 7700 & 0.0973 \\
B & & & 93 & 8.06 & 6050 & 0.1240 \\
C & $310-0$ & & 73 & 10.27 & 7700 & 0.0973 \\
D & & & 93 & 8.06 & 6050 & 0.1240 \\
\hline
\end{tabular}

-sectioned perpendicular to the welding direction (Figure 3). Metallographic observation was carried out by optical microscopy (OM) using Leica M205A optical microscope. The specimen for OM was ground, polished and etched using Tucker's $(45 \mathrm{ml} \mathrm{HCl}, 15 \mathrm{ml}$ $\mathrm{HNO}_{3}, 5 \mathrm{ml} \mathrm{HF}$ and $25 \mathrm{ml} \mathrm{H}$ O) reagent. Much care was taken to ensure location-to-location correspondence between the structural observations and hardness measurements. The nugget zone average size measurements were processed using Leica DFC295 camera and LAS software [28]. In order to obtain fracture locations of the FSW joints, the surfaces of tensile specimens were swab etched using Tucker's solution before testing. Room-temperature tensile tests were carried out at a strain rate of $3.3 \times 10^{-3} \mathrm{~s}^{-1}$ on ASTM E8M transverse tensile specimens (Figure 4). In order to asses the reproducibility, at least four specimens were tested and average value was reported. Bend testing was carried out according to EN 910 with joint centered over the mandrel. The bending specimens were tested using face and root side of the joint in tension. Vickers hardness measurement was conducted perpendicular to the welding direction, at cross section of weld joint, using digitally controlled hardness test machine (HVS-1000) applying $9.807 \mathrm{~N}$ force for $15 \mathrm{~s}$. The hardness profiles were obtained along 3 horizontal and 17 vertical directions (Figure 5). In order to obtain the hardness distribution maps a total of 183 and 187 indentations in horizontal and vertical directions, respectively, were measured.

Table 3. Testing methodology of welded joints

\begin{tabular}{lcc}
\hline ActionAction & Step & Investigation \\
\hline Non-destructive & 1 & Visual examination \\
& 2 & Penetrant examination \\
& 3 & X-Ray examination \\
Destructive & 4 & Ultrasonic examination \\
& 5 & Evaluation of macrostructure \\
& 6 & Hardness testing \\
& 7 & Tension testing \\
& 8 & Bending testing \\
\hline
\end{tabular}

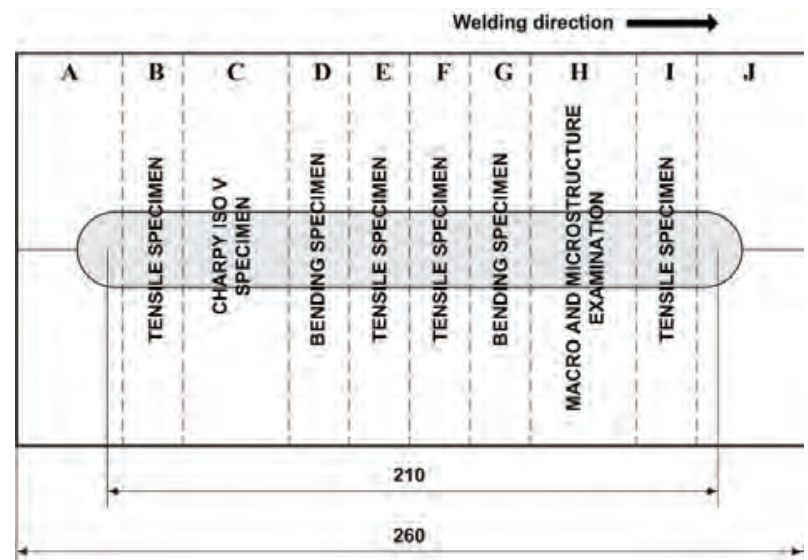

Figure 3. Schematic of specimens' locations in weld.

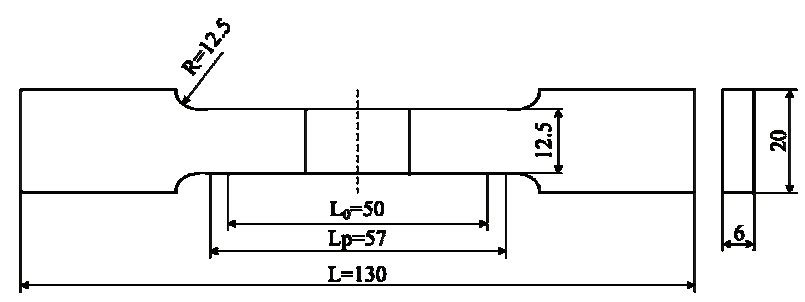

Figure 4. Shape and dimension of tensile specimens in $\mathrm{mm}$.

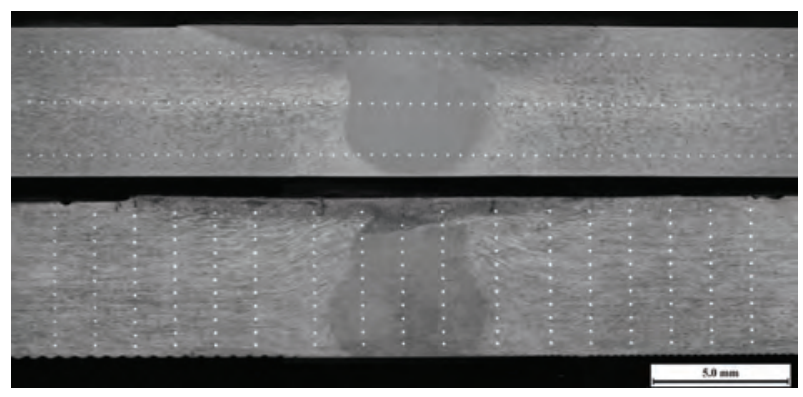

Figure 5. Horizontal (up) and vertical (down) hardness test lines.

\section{RESULTS AND DISCUSSION}

NDT examination did not detect any volume defects, proving that all were defect-free joints. Upper weld surface appearances are shown in Figure 6. It can be seen that in three cases smooth and clean surface appearance is obtained while sample $\mathrm{C}$, in comparison with other three samples, exhibits relatively smooth, but acceptable surface. 

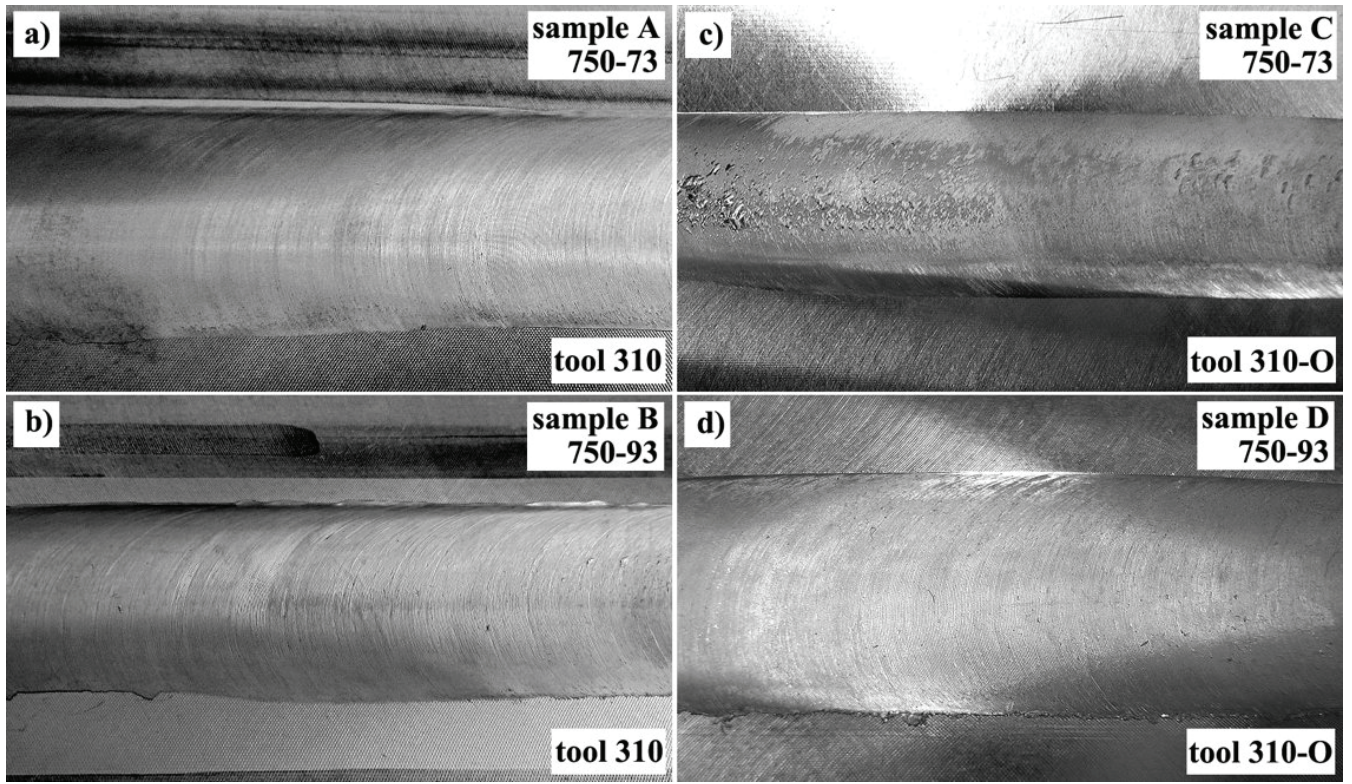

Figure 6. Joints surface appearance.

Figure 7 shows macrostructures of transverse cross section for all four joints. Macro-structural examinations confirmed NDT results; no voids, cracks or other weld defects were observed. Under the drive of tool shoulder and pin, transverse cross section structure of the weld exhibits three distinct zones: nugget zone (NZ), thermo-mechanical affected zone (TMAZ) and heat affected zone (HAZ). According to the role of shoulder and pin in NZ formation, the NZ can be subdivided into three sub-zones; the shoulder-driven zone (SDZ), the pin-driven zone (PDZ), and the swirl zone (SWZ) as shown in Figure 8c [29-32]. Pin geometry doesn't show noticeable influence on TMAZ spread out and shape. On the other hand, NZ and particularly PDZ have strong dependence on pin geometry. A comparatively large PDZ, with regular onion ring structures, a narrow SDZ and SWZ were observed. Onion ring shape in PDZ depends on welding parameters and pin design (Figure 7a-d). Furthermore, decreasing the welding speed for same rotation rate produces the finest spacing between rings. Different spacing between rings is related to the pin forward movement per revolution; i.e., at rotation rate of $750 \mathrm{rpm}$ and welding speed of 73 and $93 \mathrm{~mm} / \mathrm{min}$, tool moves 0.0973 and 0.1240 $\mathrm{mm} / \mathrm{rev}$, respectively (Table 2 ). Relationship between pin movement per revolution and onion ring width, can be described as "intermittent" behavior which is related to the pin geometry, particularly pin thread design. Similar observations and findings have been reported and suggested by other authors [33-35]. SDZ and SWZ are more or less pronounced, due to different welding parameters. For the same rotation rate PDZ becomes narrow as a welding speed is increased. However, influence of pin design on NZ and PDZ spread out
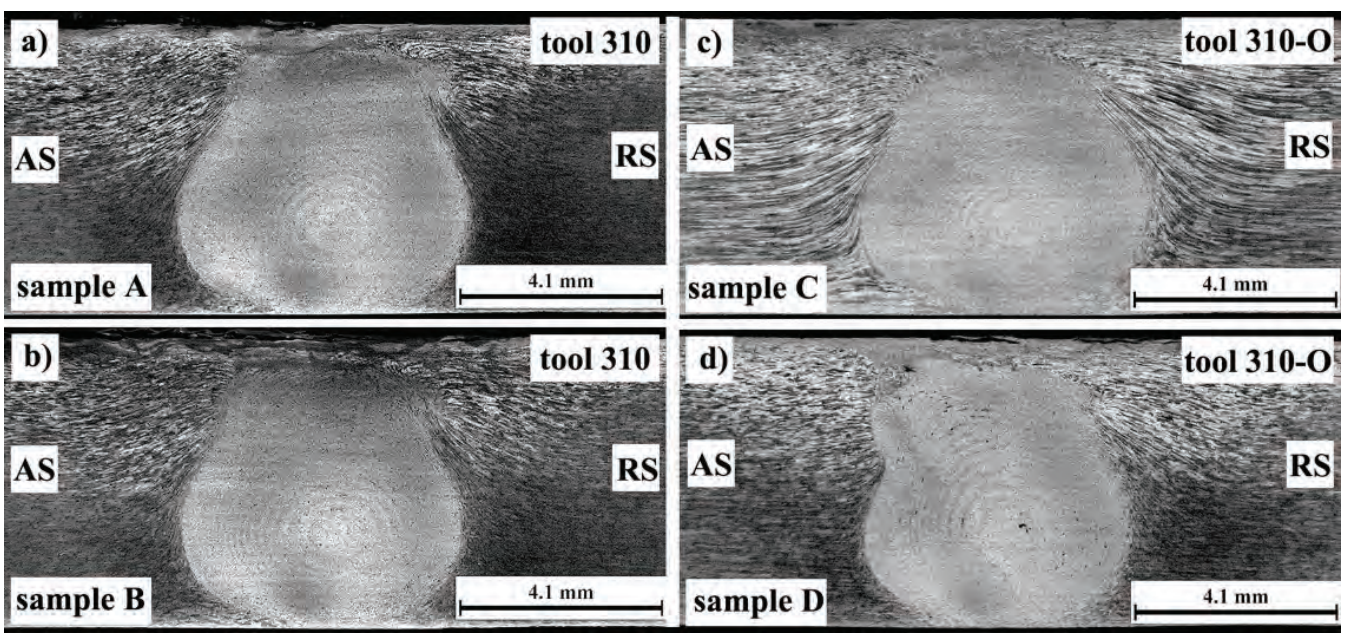

Figure 7. Macrostructure of welded joints. 

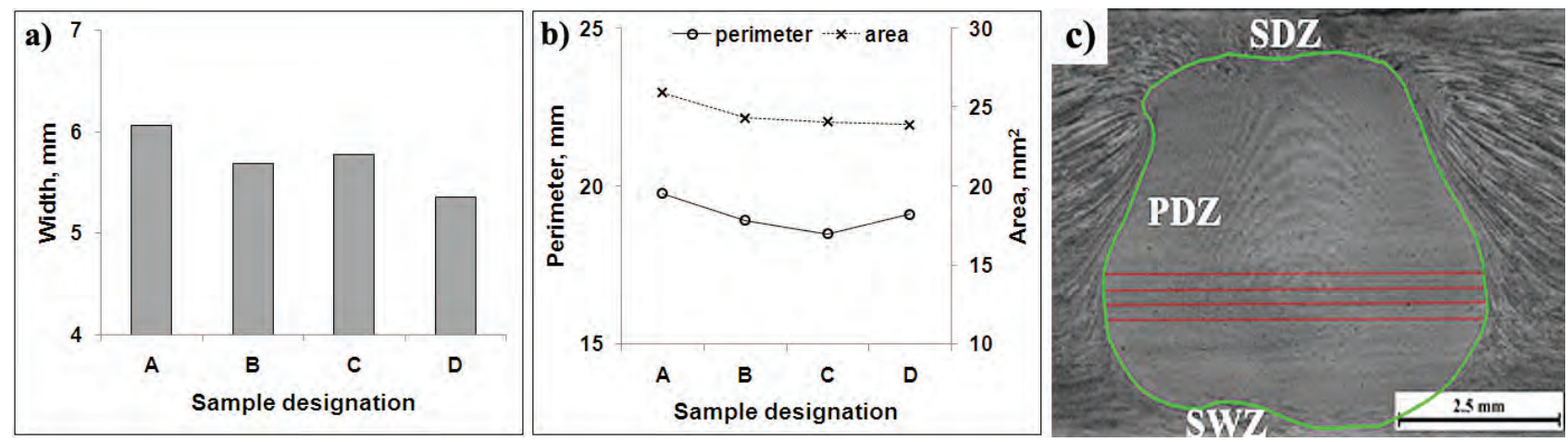

Figure 8. a) PDZ average width; b) PDZ perimeter and area; c) measurement example and general location of PDZ, SDZ and SWZ.

and shape, welded under same rotation rate and welding speed, which means that the same $R^{2} / V$ pseudo heat index is obtained. Due to small differences in pin design, PDZ width for sample $A$ and $C$ also as $B$ and $D$ are different (Figure $8 \mathrm{a}$ ). These imply that, during welding process, material flow around the pin is not the same. Mentioned behavior can be attributed to the heat input increasing as the welding speed is decreasing, relative to the rotation rate, leading to an overall increase in width of the plastic zone. On Figure 8b PDZ perimeter and area distribution are presented.

Hardness distribution maps (Figure 9) were used to determine the weakest parts of joints in terms of different process parameters and tools. Also, these maps are plotted in an attempt to predict fracture locations of joints, according to manner that the fracture location is a direct reflection of the weakest part of joint $[15,36]$. It can be determined that the low hardness zone (LHZ) was generally located at the TMAZ, rather on part of TMAZ near to the contact line between NZ and TMAZ. Low hardness is attributed to grain growth after recrystallization [37].

Average value of joint tensile properties and fracture location under investigated welding parameters are given in Table 4. Ultimate tensile strength, UTS, of each joint is lower than that of base material. Elongation of the joints is far lower than base material elongation, and its maximum is $7.5 \%$. Under the cons- a)

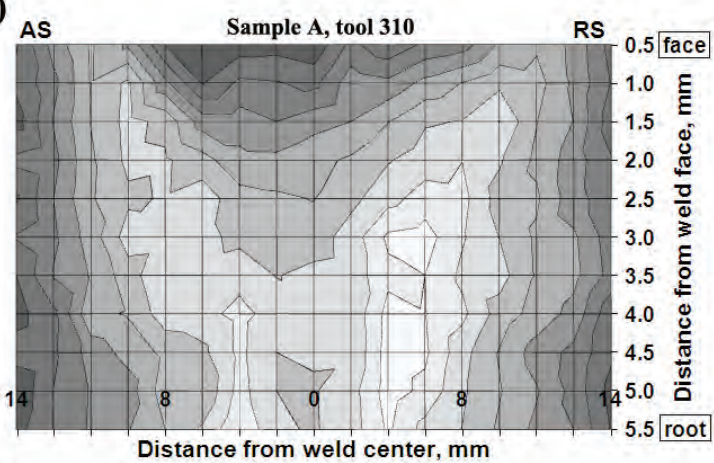

b)

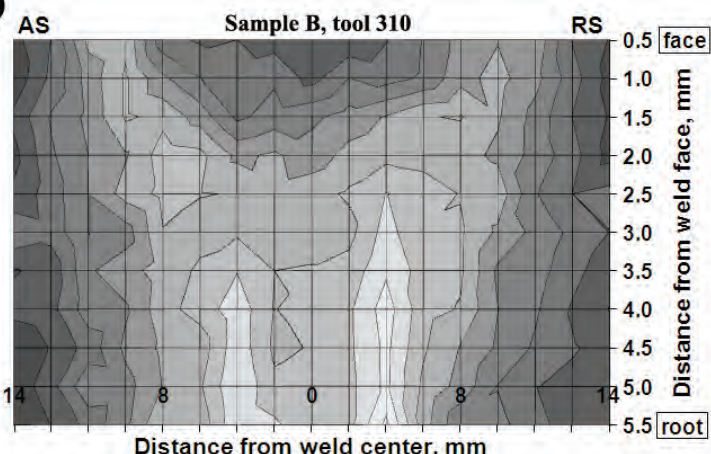

c)

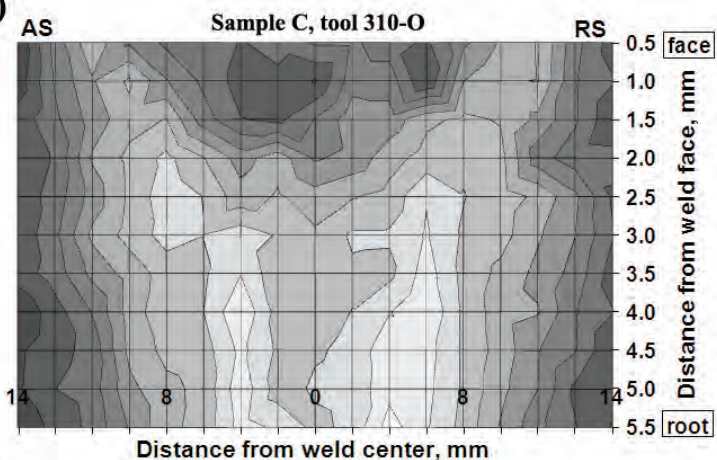

d)

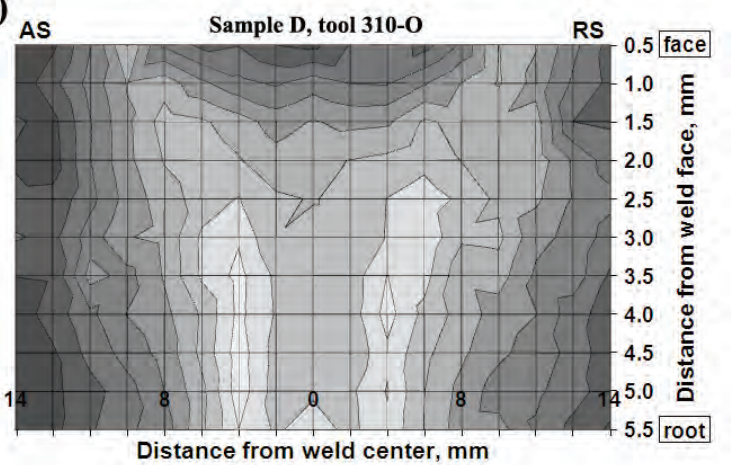

$\square 115-120 \square 120-125$

$\square 140-145 \square 145-150$

Figure 9. Hardness distribution map. 
Table 4. Tensile properties - average value

\begin{tabular}{lcccc}
\hline Sample designation & UTS / MPa & $A_{5} / \%$ & Joint efficiency, $U T S_{\mathrm{FSW}} / U T S_{\mathrm{BM}}(\%)$ & Joint efficiency $A_{\mathrm{FSW}} / A_{\mathrm{BM}}(\%)$ \\
\hline A & 395 & 7.5 & 82.2 & 41.4 \\
B & 355 & 3.9 & 73.7 & 21.7 \\
C & 365 & 4.2 & 75.9 & 23.2 \\
D & 309 & 2.8 & 64.2 & 15.5 \\
\hline
\end{tabular}

tant rotation rate of $750 \mathrm{rpm}$, for both tools, tensile strength sharply decreased when welding speed is increased. Lower tensile strength for same welding parameters (samples $A$ and $C$ and samples $B$ and $D$ ) is a consequence only due to difference in tool pin geometry and resulting microstructures. Maximum UTS in Figure 10. These results are in good agreement with hardness distribution, confirming that fracture will occur at the weakest parts of joints.

Three point bending test was carried out to examine the angle when first crack occurs. Forces when first crack occurs are also noted. The bending test includes
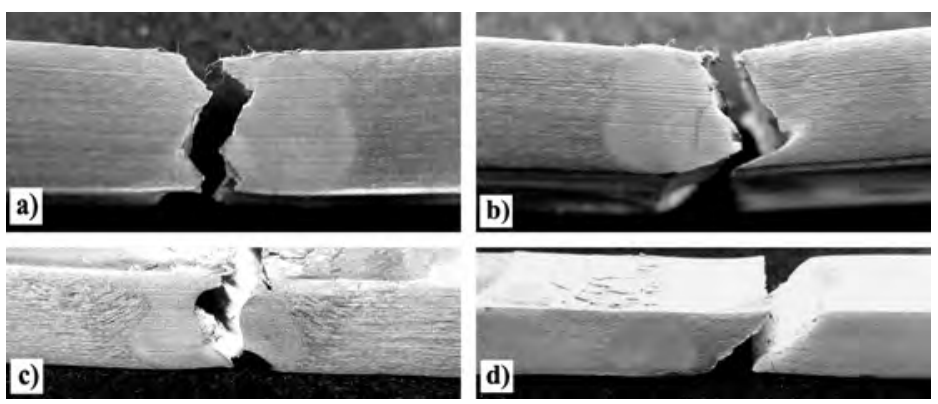

Figure 10. Typical fracture location on tensile specimen: a) NZ/TMAZ interface on AS; b) NZ/TMAZ interface on RS; c) NZ - central area; d) TMAZ/HAZ interface on RS.

was obtained for sample A welded with tool 310 and 10.27 R/V ratio, while minimum UTS were obtained for sample $D$ welded with tool $310-0$ and $8.06 R / V$ ratio. Furthermore, when compare UTS of samples welded with same welding parameters and $R / V$ ratio but with different tool (310 and 310-O), it is evident that samples welded with $310-0$ tool have 7.6 and $12.96 \%$ lower UTS. The results are similar in terms of elongation. Samples welded with 310-0 tool have 44 and $28.2 \%$ lower elongation then samples welded with 310 tool. If we take into consideration of UTS and elongation in terms of $R / V$ ratio or pseudo heat index $R^{2} / V$, it is clearly that for same ratio actual generated energy is not same and they depend on pin design moreover as on welding parameters. Therefore, it can be assumed that small modification in tool design, particularly in pin geometry, can have great influence on weld formation and mechanical properties. Thus, this implies that overall joint quality show strong dependence on combined effect of heat input and material flow states due to different welding parameters.

The fracture location is very important for understanding and improving joint mechanical properties. According to the observed findings, specimen fracture is dominantly located on NZ/TMAZ interface at AS. In order to accurately determine tensile fracture location, the cross-sections of specimen were etched, as shown bending around face (joint root are exposed to stretching) and around root (joint face are exposed to stretching). The results are shown in Figure 11. It can be seen that bending properties of joints are much lower than BM (Table 1). Most balanced results are obtain for sample A, welded with 310 tool.

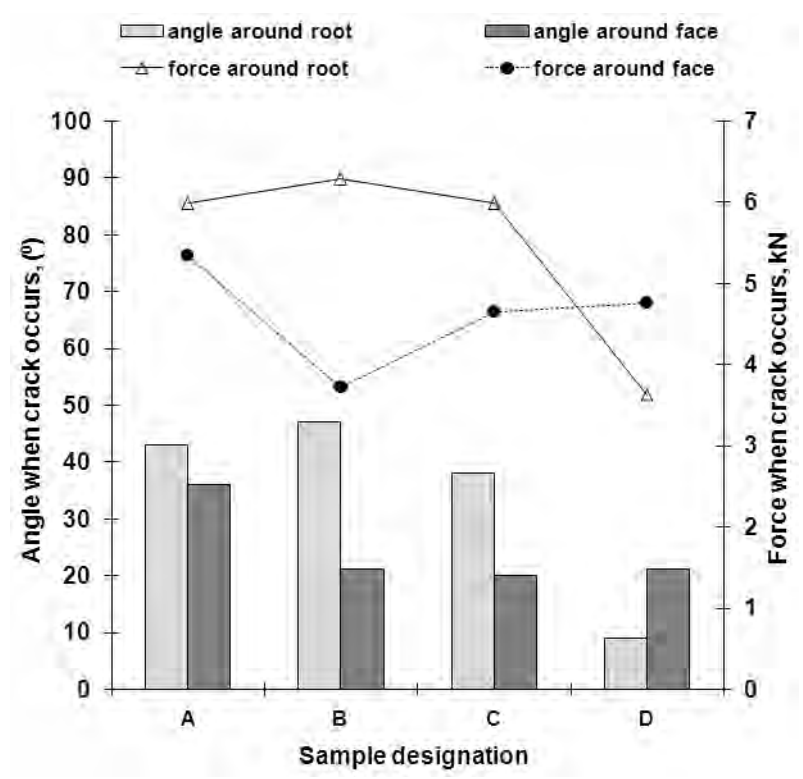

Figure 11. Bending tests results. 


\section{CONCLUSUION}

In this study combined effect of small modification of pin geometry, together with rotation and welding speed on the weldability, mechanical and structural properties of FSW 2024-T351 Al plates was investigated. In all cases, specimens were defect free, with good or acceptable fracture surface. Modification of pin geometry showed strong influence on macro structure and hardness distribution. Weak places are identified as low hardness positions close to nugget zone and are in good agreement with fracture position in tensile testing. Weld efficiency, as a measure of quality are better in case of 310 tool, while UTS values can differ up to $13 \%$ for the equal welding parameters. Therefore, it can be assumed that small modification in tool design, particularly in pin geometry, can have great influence on weld formation and mechanical properties. Sample A has shown the best properties.

\section{Acknowledgements}

The authors are indebted to Ministry of Education, Science and Technological Development of the Republic of Serbia for financial support through Project TR34018. The authors also wish to express their sincere thanks to Military Technical Institute of Serbian Army for technical support during performing friction stir welding experiments.

\section{REFERENCES}

[1] W.M. Thomas, E.D. Nicholas, J.C. Needham, M.G. Murch, P. Templesmith, C.J. Dawes, GB Patent Application No. 9125978.8, 1991.

[2] P. Vilaça, W. Thomas, Friction Stir Welding Technology in: P.M.G.P Moreira, L.F.M da Silva, P.M.S.T. de Castro (Eds.), Structural connections for lightweight metallic structures, Adv. Struct. Mater. 8 (2012) 85-124.

[3] J.N. Pires, A. Loureiro, G. Bolmsjo, Welding robots: Technology, system issues and applications, Springer, London, 2006, pp. 27-71.

[4] R.S. Mishra, Z.Y. Ma, Friction stir welding and processing, Mater. Sci. Eng. R 50 (2005) 1-78.

[5] D. Veljic, Experimental and numerical thermo-mechanical analysis of friction stir welding of high strength aluminum alloys, PhD thesis, Faculty of Mechanical Engineering, Belgrade, 2012.

[6] M. Ellis, M. Strangwood, Welding of rapidly solidified alloy 8009 (Al-8.5Fe-1.7Si-1.3V) - Preliminary study, Mater. Sci. Tech. 12 (1996) 970-977.

[7] R.S. Mishra, M.W. Mahoney, Friction stir welding and processing, ASM International, Materials Park, $\mathrm{OH}$, 2007.

[8] M. Ericsson, R. Sandstrom, Influence of welding speed on the fatigue of friction stir welds, and comparison with MIG and TIG, Int. J. Fatigue 25 (2003) 1379-1387.
[9] K. Elangovan, V. Balasubramanian, Influences of tool pin profile and welding speed on the formation of friction stir processing zone in AA2219 aluminum alloy, J. Mater. Process. Tech. 200 (2008) 163-175.

[10] R. Rail, A. De, H.K. Bhadeshia, T. DebRoy, Review: friction stir welding tools, Sci. Tech. Weld. Join. 16 (2011) 325-342.

[11] C.J. Dawes, W.M. Thomas, Development of improved tool design for FSW of aluminum, in Proceedings of $1^{\text {st }}$ International conference on friction stir welding, Thousand Oaks, TWI, USA, 1999.

[12] T. Nishihara, Development of simplified FSW tool, in Proceedings of $6^{\text {th }}$ International symposium on friction stir welding, Saint-Sauveur, Quebec, Canada, 2006.

[13] L. Dubourg, P. Dacheux, Design and properties of FSW tools: a literature review, in Proceedings of $6^{\text {th }}$ International symposium on friction stir welding, SaintSauveur, Quebec, Canada, 2006.

[14] S.R. Sharma, Z.Y. Ma, R.S. Mishra, Effect of friction stir processing on fatigue behavior of A356 alloy, Scr. Mater. 51 (2004) 237-241.

[15] H.J. Liu, H. Fujii, M. Maeda, K. Nogi, Tensile properties and fracture locations of friction-stir-welded joints of 2017-T351 aluminum alloy, J. Mater. Process. Tech. 142 (2003) 692-696.

[16] G. D'Urso, E. Ceretti, C. Giardini, G. Maccarini, The effect of process parameters and tool geometry on mechanical properties of FSW aluminum butt joints, Int. J. Mater. Form. 2(1) (2009) 303-306.

[17] Y. Zhao, S. Lin, L. Wu, F. Qu, The influence of pin geometry on bonding and mechanical properties in friction stir weld 2014 Al alloy, Mater. Lett. 59 (2005) 2948$-2952$.

[18] K.S. Arora, S. Pandey, M. Schaper, R. Kumar, Effect of process parameters on FSW of aluminum alloy 2219-T87, Int. J. Adv. Manuf. Tech. 50 (2010) 941-952.

[19] H. Abd El-Hafez, Mechanical properties and welding power of friction stirred AA2024-T35 joints, J. Mater. Eng. Perform. 20 (2011) 839-845.

[20] A.P. Reynolds, W. Tang, Z. Khandkar, J.A. Khan, K. Lindner, Relationships between weld parameters, hardness distribution and temperature history in 7050 FSW, Sci. Tech. Weld. Join. 10 (2005) 190-199.

[21] G. Buffa, J. Hua, R. Shivpuri, L. Fratini, Design of the friction stir welding tool using the continuum based FEM model, Mater. Sci. Eng., A 419 (2006) 389-396.

[22] M. Boz, A. Kurt, The influence of stirrer geometry on bonding and mechanical properties in friction stir welding process, Mater. Des. 25 (2004) 343-347.

[23] P.A. Colegrove, H.R. Shercliff, Two dimensional CFD modeling of flow round profiled FSW tooling, Sci. Tech. Weld. Join. 9 (2004) 483-492.

[24] S. Lin, Y. Zhao, Z. He, L. Wu, Modeling of friction stir welding process for tools design, Front. Mater. Sci. 5 (2011) 236-245.

[25] M. Guerra, C. Schmidt, J.C. McClure, L.E. Murr, A.C. Nunes, Flow patterns during friction stir welding, Mater. Charact. 49 (2003) 95-101. 
[26] P. Vilaça, L. Quintino, J.F. dos Santos, iSTIR - Analytical thermal model for friction stir welding, J. Mater. Process. Tech. 169 (2005) 452-465.

[27] W.J. Arbegast, P.J. Hartley, Friction stir welding technology development at Lockheed Martin Michoud space systems: an overview, in Proceedings of $5^{\text {th }}$ International conference of trends in welding research, Pine Mountain, GA, USA, 1998, p. 541.

[28] Leica Application Suite, ver. 3.8.0, Leica Microsystems Ltd., Switzerland

[29] Z. Zhang, B.L. Xiao, Z.Y. Ma, Effect of welding parameters on microstructure and mechanical properties of friction stir welded Al 2219-T6 joints, J. Mater. Sci. 47 (2012) 4075-4086.

[30] K. Kumar, S.V. Kailas, The role of friction stir welding tool on material flow and weld formation, Mater. Sci. Eng., A 485 (2008) 367-374.

[31] W.J. Arbegast, A flow partitioned deformation zone model for defect formation during friction stir welding, Scr. Mater. 58 (2008) 372-376.
[32] Z. Zhang, B.L. Xiao, Z.Y. Ma, Effect of Alclad Layer on Material Flow and Defect Formation in Friction-StirWelded 2024 Aluminum Alloy, Metall. Mater. Trans. A 42 (2011) 1717-1726.

[33] Kh.A.A. Hassan, P.B. Prangnell, A.F. Norman, D.A. Price, S.W. Williams, Effect of welding parameters on nugget zone microstructure and properties in high strength aluminum alloy friction stir welds, Sci. Tech. Weld. Join. 8 (2003) 257-268.

[34] K.N. Krishnan, On the formation of onion rings in friction stir welds, Mater. Sci. Eng., A 327 (2002) 246-251.

[35] M.A. Sutton, B. Yang, A.P. Reynolds, R. Taylor, Microstructural studies of friction stir welds in 2024-T3 aluminum, Mater. Sci. Eng., A 323 (2002) 160-166.

[36] M.J. Jones, P. Heurtier, C. Desrayaud, F. Montheillet, D. Allehaux, J.H. Driver, Correlation between microstructure and microhardness in a friction stir welded 2024 aluminium alloy, Scr. Mater. 52 (2005) 693-697.

[37] K.V. Jata, S.L. Semiatin, Continuous dynamic recrystallization during friction stir welding of high strength aluminum alloys, Scr. Mater. 43 (2000) 743-749.

\title{
IZVOD
}

\section{UTICAJ GEOMETRIJE TRNA ALATA NA MEHANIČKE I STRUKTURNE KARAKTERISTIKE SUČEONOG SPOJA ALUMINIJUMSKE LEGURE 2024-T351 ZAVARENOG POSTUPKOM FSW}

\author{
Igor Z. Radisavljević ${ }^{1}$, Aleksandar B. Živković ${ }^{2}$, Vencislav K. Grabulov ${ }^{3}$, Nenad A. Radović ${ }^{4}$ \\ ${ }^{1}$ Vojnotehnički institut, Beograd, Srbija \\ ${ }^{2}$ GOŠA FOM, Smederevska Palanka, Srbija \\ ${ }^{3}$ Institut za ispitivanje materijala, Beograd, Srbija \\ ${ }^{4}$ Tehnološko-metalurški fakultet, Beograd, Srbija
}

(Naučni rad)

U radu je ispitavano kakav zajednički, kombinovani uticaj brzina rotacije alata, brzina zavarivanja i mala promena u geometriji trna alata imaju na zavarljivost, mehaničke i strukturne karakteristike sučeonog spoja Al legure 2024-T351 zavarene primenom FSW (zavarivanje trenjem alatom) postupka zavarivanja. Zavarivane su ploče dimenzija $260 \mathrm{~mm} \times 65 \mathrm{~mm} \times 6 \mathrm{~mm}$. Ploče su pre zavarivanja mašinski obrađene i kruto stegnute za potpornu ploču. Zavarivanje je izvedeno u pravcu valjanja ploča, na alatnoj glodalici prilagođenoj postupku FSW. Dužina svakog zavarenog spoja iznosila je oko $210 \mathrm{~mm}$. Korišćena su dva alata sa veoma slično profilisanim trnovima. Razlika u dizajnu trna alata je u obliku zavojnice, normalna (klasična) kod alata oznake 310 odnosno zaobljena za alat 310-0. Zavarivanje je izvedeno pri brzini rotacije alata od 750 o/min i brzinama zavarivanja 73 i 93 $\mathrm{mm} / \mathrm{min}$. Ukupno su zavarene četiri kombinacije spojeva. U svim slučajevima dobijen je zavareni spoj bez prisustva grešaka, sa glatkom odnosno delimično hrapavom površinom zavara. Prisutne su tri različite oblasti u spoju - grumen, zona termomehaničkog uticaja i zona uticaja toplote. Promene u dizajnu trna alata imaju znatnog uticaja na makrostrukturu spoja i raspodelu tvrdoće kroz spoj. Mapiranjem spoja, na osnovu raspodele tvrdoće, određene su oblasti sa najnižim vrednostima tvrdoće a nalaze se u neposrednoj blizini grumena, tačnije na liniji dodira grumena i zone termomehaničkog uticaja. Položaj oblasti najmanje tvrdoće je u saglasnosti sa mestom preloma zateznih epruveta. Efikasnost spoja, kao ocena kvaliteta spoja, je veća kod spojeva zavarenih alatom 310. U zavisnosti od alata, pri istim parametrima zavarivanja dobijene su različite vrednosti zateznih čvrstoća a razlika iznosi do $13 \%$. Pokazano je da mala modifikacija u dizajnu trna alata ima velikog uticaja na formiranje spoja i njegove mehaničke karakteristike.

Ključne reči: Zavarivanje trenjem alatom - Geometrija trna alata • Kvalitet spoja • Al legura $2024 \bullet$ Uneta toplota 